\title{
Biogenic Amines Profile of Serbian Traditional Sausage in Relation to Raw Material and Production Conditions
}

\author{
Tatjana Tasić ${ }^{1}$, Predrag Ikonić ${ }^{1}$, Ljiljana Petrović ${ }^{2}$, Anamarija Mandić ${ }^{1}$, Snežana Škaljac ${ }^{2}$, Marija Jokanović ${ }^{2}$ \\ Vladimir Tomović ${ }^{2}$ Branislav Šojić ${ }^{2}$, Maja Ivić ${ }^{2}$ and Natalija Džinić ${ }^{2}$ \\ 1. Institute for Food Technology, University of Novi Sad, Bulevar Cara Lazara 1, Novi Sad 21000, Serbia \\ 2. Faculty of Technology, University of Novi Sad, Bulevar Cara Lazara 1, Novi Sad 21000, Serbia
}

\begin{abstract}
Petrovská klobása is a traditional dry fermented sausage produced in the Autonomous Province of Vojvodina. Formation of nine biogenic amines was determined in three sausage groups produced from hot deboned (A1) and cold meat (B1, B3) during drying and ripening in traditional room (A1, B1) and in industrial ripening chamber (B3). Dansyl chloride derived amines were analysed by high-performance liquid chromatography with diode-array detector (HPLC-DAD) on Eclipse XDB-C18 column. Histamine, the most important amine from food safety point of view, was not found in any of the analyzed samples. Serotonin and spermidine were also not detected in any samples, while spermin was determined in all analyzed samples. At the end of drying, phenylethylamine was the predominant amine in A1 sausage group $(51.6 \mathrm{mg} / \mathrm{kg})$, and tryptamine in B1 $(38.1 \mathrm{mg} / \mathrm{kg})$ and B3 $(28.7$ $\mathrm{mg} / \mathrm{kg}$ ) sausage groups. At the end of ripening, tryptamine was the predominant biogenic amine in all sausage groups (133, 121 and $39.8 \mathrm{mg} / \mathrm{kg}$ in A1, B1 and B3 groups, respectively). Total level of biogenic amines in all investigated sausages did not exceed 174 $\mathrm{mg} / \mathrm{kg}$ at the end of drying and $238 \mathrm{mg} / \mathrm{kg}$ at the end of ripening period. Tryptamine and cadaverine may be used as indicators of total biogenic amines for sausages produced in traditional and indusrial conditions from hot deboned and cold meat.
\end{abstract}

Key words: Biogenic amines, traditional dry fermented sausage Petrovská klobása, raw material, production conditions.

\section{Introduction}

Biogenic amines are organic bases naturally present in many foods $[1,2]$. They are formed during ripening processes by microorganisms with ability to synthesize amino acid decarboxylase and high proteolytic potential or they are formed as a result of food spoilage [1, 3-5]. Consumption of food containing high amounts of biogenic amines may be harmful [4, 6-9]. High levels of biogenic amines present in foods may cause migraine, headache, gastric and intestinal problems and pseudo allergic responses $[3,6]$.

Histamine is considered as the most toxic biogenic amine [1, 2, 6, 8]. It has vasoactive properties and may cause urticaria, hypotension, headache, flushing, abdominal cramps and other problems for human health [10]. Thus, it is important to monitor biogenic

Corresponding author: Tatjana Tasić, Ph.D., research field: meat science. amines in fresh and processed foods, not only due to their toxicity, but also because they can be a useful index of spoilage or ripening stage [1, 4, 11-14].

Petrovská klobása is a traditional dry fermented sausage which production dates back to 250 years ago. It has been produced in the area nearby Bački Petrovac town in the Autonomous Province of Vojvodina, Republic of Serbia. Production is carrying out in small household enterprises in December, when temperatures are around $0{ }^{\circ} \mathrm{C}$ and lower, using traditional methods. This product has been protected with designation of origin (PDO) according to the Serbian legislation due to its specific and recognizable characteristics [15-17].

Traditionally, homemade Petrovská klobása is produced exclusively from pork meat and fat, red hot paprika powder, salt, crushed garlic, caraway and sugar. Ripen sausage is characterized by specific hot taste, aromatic and spicy flavor, dark red color and 
hard consistency [15-17]. Traditional production of Petrovská klobása does neither include the use of starter cultures nor additives (nitrite, gluconodeltalactone, etc.), in contrary to industrial production of fermented sausages. Fermentation and ripening processes, as well as final quality of the product, are influenced by indigenous microflora of raw materials and environment. During ripening process, activity of present microflora causes decarboxylation of amino acids and formation of biogenic amines.

Great fluctuations of biogenic amine content are reported in the same type of products. These differences depend on numerous variables: qualitative and quantitative composition of microflora, chemical and physical factors, hygienic procedure adopted during production and availability of amino acids as precursors. Large variability in type and quantity of biogenic amines, even in sausages produced under controlled conditions, indicates that their formation depends on a complex interaction of factors $[2,8]$. Dry fermented sausages can be a source of biogenic amines, due to high amount of proteins present in these products, and they are precursors for decarboxylation which is occurring during ripening [2].

Large variations in biogenic amine content and composition were found in traditional fermented sausages produced in European countries, even though usually tyramine is the most important biogenic amine [18-20]. According to available literature, there are only few data concerning biogenic amines content in traditional dry fermented sausages from Serbia.

The aim of this paper was to determine the formation of nine biogenic amines in Petrovská klobása during drying and ripening period, with regard to raw material (hot deboned meat or cold meat) and processing conditions (traditional room or industrial ripening chamber).

\section{Materials and Methods}

\subsection{Sausage Samples}

Three groups of sausages were examined in this study (Table 1). Traditionally Petrovská klobása is made from hot deboned meat, but as in recent years, food safety is an increasingly important public health issue, as well as because of some technological disadvantages of hot deboned meat processing, producers have to slightly modify the production conditions to meet the requirements.

All groups of sausages were produced in traditional manner. Minced lean pork meat $80 \%$ and pork fat $20 \%$ were mixed with red hot paprika powder $(2.50 \%)$, salt $(1.80 \%)$, crushed garlic $(0.20 \%)$, caraway $(0.20 \%)$ and sugar $(0.15 \%)$. All ingredients were mixed approximately $10 \mathrm{~min}$ using traditional technique. The mixture was stuffed into natural casings - pig intestine (rectum) around $40 \mathrm{~cm}$ long and near $5 \mathrm{~cm}$ in diameter. Traditionally processed sausages were smoked using cool procedure for $10 \mathrm{~d}$ with pauses, while sausages processed in industrial conditions were smoked for $6 \mathrm{~h}$ (12 $\times 30 \mathrm{~min})$, during $3 \mathrm{~d}$.

According to Serbian legislation, moisture content for dry fermented sausages have to be less than $35 \%$. Sausages from $\mathrm{A} 1$ and $\mathrm{B} 1$ group dried in traditional room (temperature from $2.6{ }^{\circ} \mathrm{C}$ to $12.4{ }^{\circ} \mathrm{C}$; relative humidity from $43.3 \%$ to $93.0 \%$ ) needed $90 \mathrm{~d}$ to reach required moisture content, while sausages from B3 group dried in industrial ripening chamber (temperature

Table 1 Raw material, processing conditions and days of sampling for examined sausage groups.

\begin{tabular}{llll}
\hline Group of sausages & Raw material & Processing conditions & Days of sampling \\
\hline A1 & $\begin{array}{l}\text { Hot deboned meat } \\
(2 \mathrm{~h} \text { post mortem })\end{array}$ & Traditional room & $0,2,6,9,12,15,30,60,90,120$ \\
B1 & $\begin{array}{l}\text { Cold meat } \\
(24 \mathrm{~h} \text { post mortem })\end{array}$ & Traditional room & $0,2,6,9,12,15,30,60,90,120$ \\
B3 & $\begin{array}{l}\text { Cold meat } \\
(24 \mathrm{~h} \text { post mortem })\end{array}$ & Industrial ripening chamber & $0,2,6,9,12,15,30,45,120$ \\
\hline
\end{tabular}


of $10{ }^{\circ} \mathrm{C}$; relative humidity $\sim 75 \%$ ) reached this value after $45 \mathrm{~d}$, what determined the sausage sampling.

At the end of drying period, the 90th day for A1 and B1, and 45th day for B3, sausages from all groups were vacuum packed and ripened at $10{ }^{\circ} \mathrm{C}$ and $75 \%$ relative humidity further on until the 120 th day, when it achieves the optimum quality $[15,17]$.

Samples of $250 \mathrm{~g}$ were homogenized on Waring 8010ES Blender, USA with capacity 1 L and speed $18,000 \mathrm{rpm}$ around $15 \mathrm{~s}$ with temperature after homogenization $<10^{\circ} \mathrm{C}$. Homogenized samples were stored at $-20{ }^{\circ} \mathrm{C}$ until analyzed.

All determinations were performed on three samples from each batch in duplicate.

\subsection{Biogenic Amines Determination}

Tryptamine, phenylethylamine, putrescine, cadaverine, histamine, serotonin, tyramin, spermidine and spermine were determined following the high-performance liquid chromatography (HPLC). Sample extraction and derivatization were done according to Eerola et al. [21]. Briefly, $2 \mathrm{~g}$ of each sample were weight and put into test tube. Appropriate amount of internal standard was added and sample was homogenyized with $10 \mathrm{~mL} 0.4 \mathrm{M}$ perchloric acid using Ultraturrax blender. The homogenate was centrifuged at 3,000 rpm for $10 \mathrm{~min}$, and supernatant was filtered into $25 \mathrm{~mL}$ bottle. Extraction was repeated with $10 \mathrm{~mL} 0.4 \mathrm{M}$ perchloric acid solution, mixed with Vortex and centrifuged as before. Supernatants were combined and adjusted to $25 \mathrm{~mL}$ with $0.4 \mathrm{M}$ perchloric acid. After, $1 \mathrm{~mL}$ of sample extract was made alkaline by adding $200 \mu \mathrm{L} 2$ $\mathrm{M} \mathrm{NaOH}$ and buffered with $300 \mu \mathrm{L}$ saturated $\mathrm{NaHCO}_{3}$. Then, $2 \mathrm{~mL}$ of dansyl chloride solution was added and the reaction mixture was incubated at $40{ }^{\circ} \mathrm{C}$ for $45 \mathrm{~min}$. Residual dansyl chloride was removed by adding $100 \mu \mathrm{L}$ ammonia. After $30 \mathrm{~min}$, mixture was adjusted to $5 \mathrm{~mL}$ with acetonitrile, filtered $(0.45 \mu \mathrm{m}$, PTFE, MS Springer filter) and analyzed.

HPLC analysis was performed by using a liquid chromatography (Agilent 1200 series), equipped with a diode array detector (DAD), Chemstation Software (Agilent Technologies), a binary pump, an online vacuum degasser, an auto sampler and a thermostated column compartment, on an Agilent, Eclipse XDB-C18, $1.8 \mu \mathrm{m}, 4.6 \mathrm{~mm} \times 50 \mathrm{~mm}$ column.

Solvent gradient was performed by varying the proportion of solvent A (acetonitrile) to solvent B (water) as follows: initial $50 \% \mathrm{~B}$, linear gradient to $10 \% \mathrm{~B}$ in $7.6 \mathrm{~min}, 10 \% \mathrm{~B}$ to $10 \mathrm{~min}$, linear gradient to $50 \% \mathrm{~B}$ in $2 \mathrm{~min}$. System was equilibrated $3 \mathrm{~min}$ before next analysis. Flow rate was $1.5 \mathrm{~mL} / \mathrm{min}$, column temperature was $40{ }^{\circ} \mathrm{C}$ and $5 \mu \mathrm{L}$ of sample was injected [22]. Detection limits of the amines were determined to be $0.1 \mu \mathrm{g} / \mathrm{g}$ for putrescine and spermidine, $0.167 \mu \mathrm{g} / \mathrm{g}$ for cadaverine and tyramin, $0.25 \mu \mathrm{g} / \mathrm{g}$ for tryptamine, phenylethylamine and histamine, and $0.5 \mu \mathrm{g} / \mathrm{g}$ for serotonin and spermine, respectively.

\subsection{Statistical Analysis}

Statistical analysis in biogenic amines content between groups of sausages (A1, B1 and B3) was done at the end of drying and at the end of ripening period. One way ANOVA post-hoc (Duncan test) was performed. Differences were considered significant at $P<0.05$. Correlation coefficients among biogenic amines were also calculated. The software package Statistica 9.1 for Windows, Stat Soft, Tulsa, Oklahoma, USA, 2009 was used.

\section{Results and Discussion}

Formation of biogenic amines in traditional dry fermented sausage Petrovská klobása was determined using HPLC method for analysis. Chromatographic separation of nine biogenic amines was completed in 8 $\min$.

\subsection{Formation of Biogenic Amines}

Formation of tryptamine, phenylethylamine, putrescine, cadaverine and tyramine are shown in 
Fig. 1. Tryptamine content in samples detected varied from $0 \mathrm{mg} / \mathrm{kg}$ to $133 \mathrm{mg} / \mathrm{kg}$. The concentrations ranged from $14.7 \mathrm{mg} / \mathrm{kg}$ (A1) to $38.1 \mathrm{mg} / \mathrm{kg}$ (B1) at the end of drying, and from $39.8 \mathrm{mg} / \mathrm{kg}$ (B3) to 133 $\mathrm{mg} / \mathrm{kg}$ (A1) at the end of ripening when tryptamine was the prevailing biogenic amine in all groups of sausges. Tryptamine concentrations were significantly different $(P<0.05)$ between all groups at the end of drying, as well as at the end of ripening period. At the end of ripening, concentrations of tryptamine in sausages dried in traditional manner were much more closer $(133 \mathrm{mg} / \mathrm{kg}$ and $121 \mathrm{mg} / \mathrm{kg}$, for $\mathrm{A} 1$ and $\mathrm{B} 1$, respectively) and higher than tryptamine concentration for sausages dried in industrial chamber $(39.8 \mathrm{mg} / \mathrm{kg}$ for B3).

The content of phenylethylamine, aromatic amine, ranged from $0 \mathrm{mg} / \mathrm{kg}$ (B3) to $51.6 \mathrm{mg} / \mathrm{kg}$ (A1) at the end of drying, and from $16.6 \mathrm{mg} / \mathrm{kg}$ (B3) to 43.1 $\mathrm{mg} / \mathrm{kg}$ (B1) at the end of ripening. The differences between all groups at the end of drying, as well as at the end of ripening, were significant $(P<0.05)$. Unlike B3, where phenylethylamine was found only

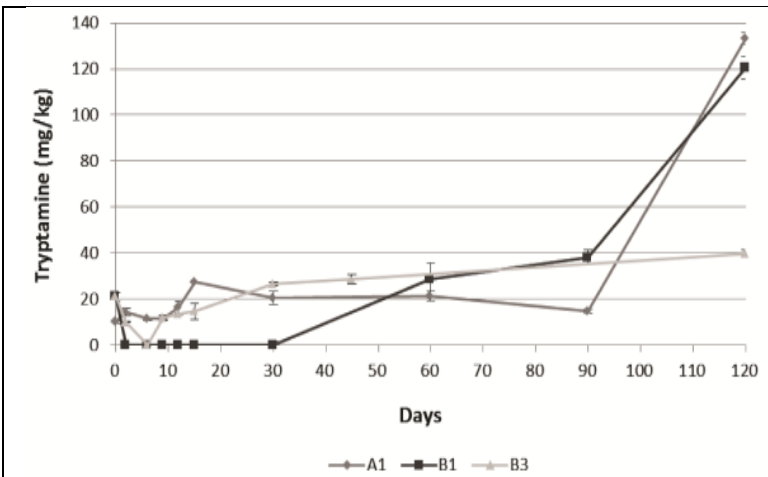

(a) Tryptamine

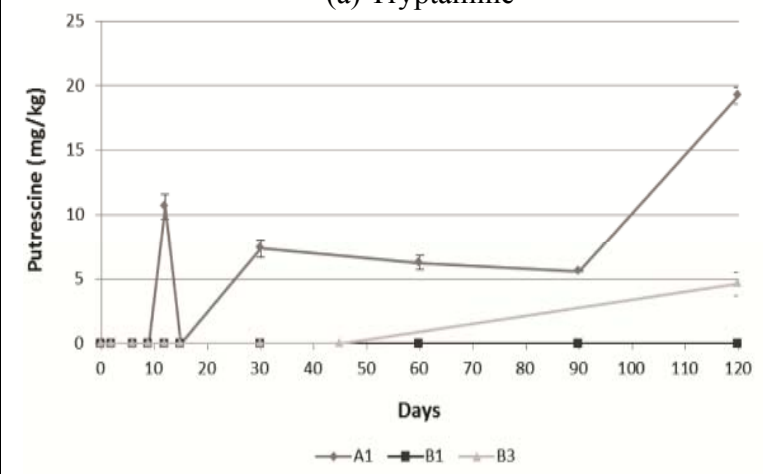

(c) Putrescine

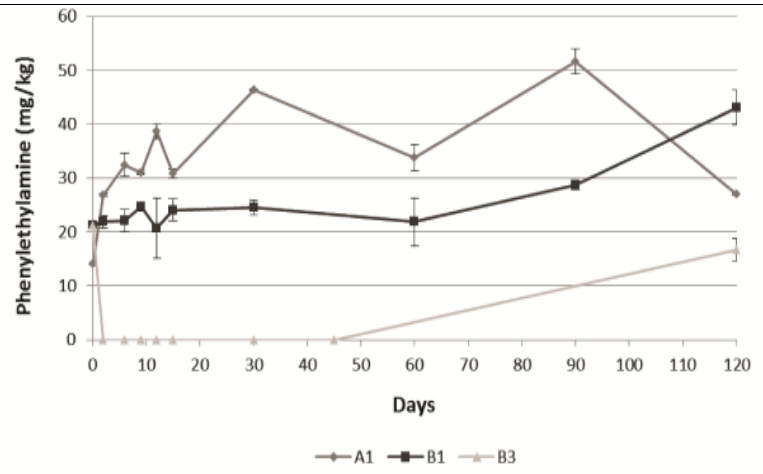

(b) Phenylethylamine

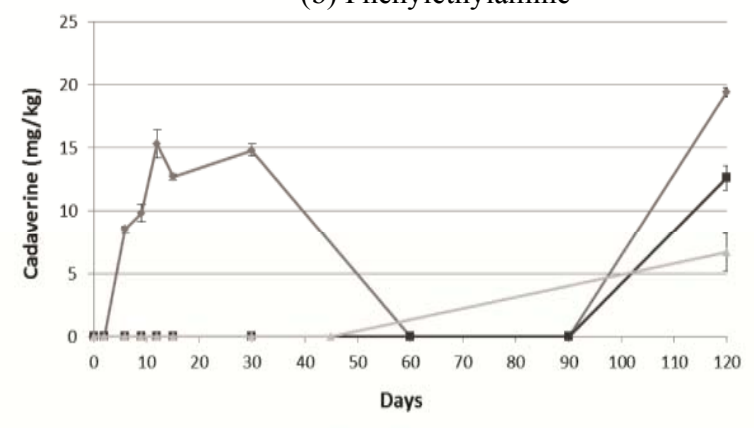

(d) Cadaverin

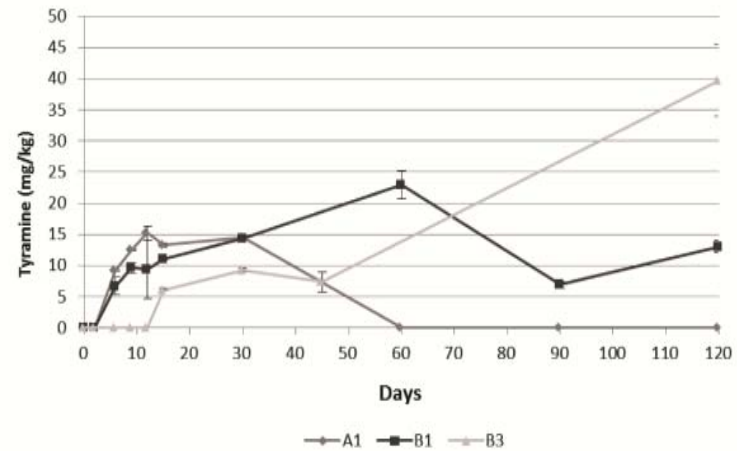

(e) Tyramine

Fig. 1 Formation of tryptamine, phenylethylamine, putrescine, cadaverine and tyramine in examined sausage groups during drying and ripening. 
on the 120th day, in A1 and B1 this amine was found in all samples analyzed at the mentioned days.

At the end of drying period, putrescine content in A1 group was $5.54 \mathrm{mg} / \mathrm{kg}$. On the contrary to A1, in B1 and B3 groups putrescine was not detected during whole drying period, while at the end of ripening period putrescine was found in B3 group, with values of $19.2 \mathrm{mg} / \mathrm{kg}$ and $4.6 \mathrm{mg} / \mathrm{kg}$ for $\mathrm{A} 1$ and $\mathrm{B} 3$, respectively. Formation of cadaverine was similar. This amine was not detected in B1 and B3 groups during whole drying period, while in A1 group it was detected until the 60th day.

Unlike the putrecin, cadaverin was found in all groups at the end of ripening period in the range from $6.69 \mathrm{mg} / \mathrm{kg}$ (B3) to $19.4 \mathrm{mg} / \mathrm{kg}$ (A1). These differences could be explained by the larger amount of diamines, especially cadaverine in the raw material (hot deboned meat) of weaker microbiological quality, with a relatively higher number of Enterobacteriaceae, as it was refered by Bover-Cid et al. [23].

Histamine and serotonin were not detected in any of the analyzed samples. Since histamine is well known for its toxity, the absence of this biogenic amine is very important from toxicology point of view. Histamine was not found in examined sausages because of low temperatures applied during smoking, drying and ripening. Both drying models used in this study were slow drying models with the maximum temperatures up to $12.4{ }^{\circ} \mathrm{C}$, which are not adequate conditions for histamine formation [22].

Tyramine, reported as the most abundant amine in fermented sausages [2, 8, 18, 24, 25], was determined in the highest concentration in sausages dried and ripened in industrial chamber, while in sausages produced from hot deboned meat dried and ripened in traditional room, this amine was not determined at both end of drying and ripening period. Observed values between all groups were significantly different $(P<0.05)$.

The great variety in type and content of biogenic amines was determined in traditional dry fermented sausages. Tyramine and putrescine were the most abundant biogenic amines found in different types of dry fermented sausages produced in Finland, while in Danish sausages, cadaverine was found in high amounts. In French sausages, putrescine, cadaverine, tyramine and histamine were detected. And in sausages produced in Southern Italy, tyramine was the most important biogenic amine, followed by putrescine and cadaverine, while 2-phenylethylamine was found at low levels [4].

\subsection{Formation of Polyamines}

In terms of polyamines content (Table 2), spermidine was not found in any sample, while spermine is the only biogenic amine which was found in all groups during whole time of drying and ripening period in the range from $21.5 \mathrm{mg} / \mathrm{kg}$ to $101 \mathrm{mg} / \mathrm{kg}$. Quantity and trend of spermine changes during dry sausage production were nearly the same in A1 and B3 group, while in B1 group, the increase was observed after the 30th day. Thus, at the end of drying period, content of spermine in B1 group was more than $100 \%$ higher than this content in $\mathrm{A} 1$ and $\mathrm{B} 3$.

It is well known that spermine originate from meat as the main raw material, and its level mainly remains stable with slight increase or decrease depending on different technological factors during production [26]. On the contrary to other biogenic amines, polyamine synthesis is a more complex process. Although the first few steps also include a decarboxylation reaction, for spermine syntheses, additional enzymes are required [26]. The polyamines spermine and spermidine always occur in fresh meat, and their relevant presence in sausages has been related to drying process involved in the manufacture of this product [24]. Nevertheless, enterobacteria and some lactic acid bacteria isolated from sausages [27], and enterococci from cheese [28] were able to produce these polyamines. Obviously, in B1 group, such conditions were made. Obtained value for spermine is lower than this value found in different dry fermented 
Table 2 Content of spermidine and spermin in examined sausage groups during drying and ripening.

\begin{tabular}{lllllll}
\hline \multirow{2}{*}{$\begin{array}{l}\text { Drying and ripening } \\
\text { period (d) }\end{array}$} & \multicolumn{9}{c}{ Spermidin } & \multicolumn{3}{c}{ Polyamines content $(\mathrm{mg} / \mathrm{kg})$} \\
\cline { 2 - 4 } \cline { 5 - 6 } & A1 & B1 & B3 & A1 & B1 & B3 \\
\hline 0 & ND & ND & ND & $23.10 \pm 0.06^{\mathrm{a}, \mathrm{b}}$ & $24.80 \pm 1.08^{\mathrm{a}, \mathrm{b}, \mathrm{c}}$ & $24.80 \pm 1.08^{\mathrm{a}, \mathrm{b}, \mathrm{c}}$ \\
2 & ND & ND & ND & $32.80 \pm 0.22^{\mathrm{d}}$ & $22.80 \pm 0.53^{\mathrm{a}}$ & $26.50 \pm 1.62^{\mathrm{c}}$ \\
6 & ND & ND & ND & $31.60 \pm 0.08^{\mathrm{d}}$ & $24.80 \pm 1.03^{\mathrm{a}, \mathrm{b}, \mathrm{c}}$ & $24.60 \pm 1.85^{\mathrm{a}, \mathrm{b}, \mathrm{c}}$ \\
9 & ND & ND & ND & $33.70 \pm 12.07^{\mathrm{d}}$ & $26.40 \pm 0.55^{\mathrm{b}, \mathrm{c}}$ & $26.70 \pm 0.46^{\mathrm{c}}$ \\
12 & ND & ND & ND & $33.40 \pm 2.47^{\mathrm{d}}$ & $30.60 \pm 0.89^{\mathrm{d}}$ & $27.20 \pm 0.38^{\mathrm{c}}$ \\
15 & ND & ND & ND & $31.20 \pm 0.36^{\mathrm{d}}$ & $26.90 \pm 2.53^{\mathrm{c}}$ & $30.80 \pm 1.09^{\mathrm{d}}$ \\
30 & ND & ND & ND & $32.20 \pm 1.31^{\mathrm{d}}$ & $25.10 \pm 0.41^{\mathrm{a}, \mathrm{b}, \mathrm{c}}$ & $41.30 \pm 2.40^{\mathrm{e}}$ \\
45 & - & - & ND & - & - & $41.80 \pm 5.32^{\mathrm{e}}$ \\
60 & ND & ND & - & $33.60 \pm 16.17^{\mathrm{d}}$ & $72.10 \pm 2.51^{\mathrm{f}}$ & - \\
90 & ND & ND & - & $41.50 \pm 2.96^{\mathrm{e}}$ & $101.00 \pm 5.67^{\mathrm{g}}$ & - \\
120 & ND & ND & ND & $38.70 \pm 0.36^{\mathrm{e}}$ & $38.60 \pm 2.53^{\mathrm{e}}$ & $25.60 \pm 1.09^{\mathrm{a}, \mathrm{b}, \mathrm{c}}$ \\
\hline
\end{tabular}

Results are expressed as means \pm standard deviations. ND: not detected.

${ }^{\mathrm{a}-\mathrm{g}}$ Means with different letters in the same raw are significantly different $(P<0.05)$.

sausages after ripening, except in Saucisson (industrial) where spermine content ranged from $59 \mathrm{mg} / \mathrm{kg}$ to 119 $\mathrm{mg} / \mathrm{kg}[2]$.

\subsection{Total Biogenic Amine Content}

The total level of biogenic amines in all investigated sausages did not exceed the value of 174 $\mathrm{mg} / \mathrm{kg}$ at the end of drying period and $238 \mathrm{mg} / \mathrm{kg}$ at the end of ripening period, respectively (Fig. 2). At the end of drying, significant differences $(P<0.05)$ were observed between all groups of sausages, while at the end of ripenig, significant differences were obtained between groups of sausages produced in traditional room (A1 and B1) and in industrial ripening chamber (B3).

The difference in content of biogenic amines was observed between sausage mixtures produced from hot deboned (A) and cold meat (B) (Fig. 2). Higher content in $\mathrm{B}$ mixture could be explained by longer activity of endogenous peptidases ( $24 \mathrm{~h})$, which is mainly active during this stage [29, 30].

In the later stages of drying and ripening, when egzopeptidases [31, 32] generate amino acids, application of slow fermented drying model in sausage production results in similar biogenic amines formation, especially in groups B1 and B3. Decrease in total biogenic amines content at the 60th day in A1 group was obtained possibly due to their transformation into compounds of the aroma and taste holder. Moreover, aminogenesis and accumulation of biogenic amines are higher and faster at higher processing temperatures and relative humidity [14].

\subsection{Correlations between Biogenic Amines Contents}

Correlation coefficients between individual and total biogenic amines are presented in Table 3 . There are very significant correlations between total biogenic amines content and tryptamine and cadaverine concentrations in all examined groups, while very significant correlations between total biogenic amines content and phenyletylamine, putrescine and tyramine concentrations were observed only for sausages ripened in industrial chamber. Consequently, certain biogenic amines, such as tryptamine and cadaverine may be used as indicators of total biogenic amines for sausages produced in traditional and industrial conditions from hot deboned and cold meat.

Based on results obtained in this study, regarding biogenic amines as food safety parameter, it is obvious that both hot deboned meat and cold meat could be used for sausage production. If we consider the 


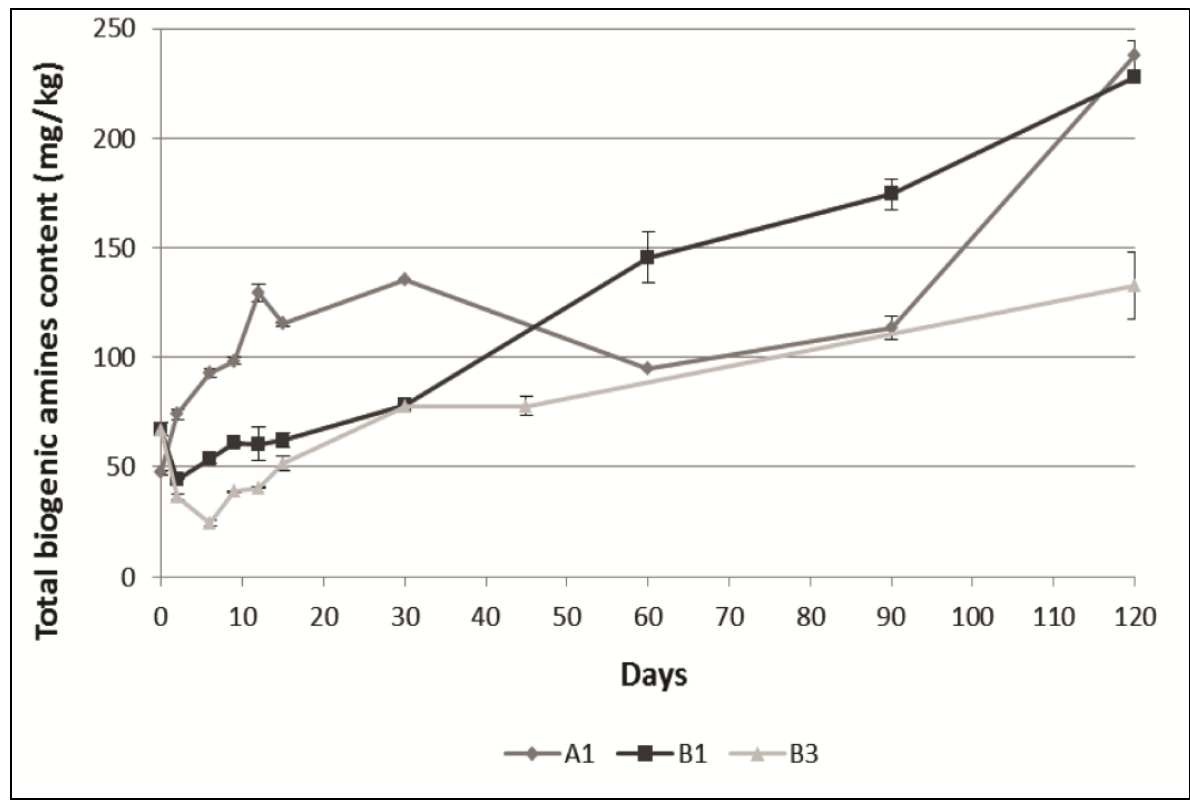

Fig. 2 Total biogenic amine content in examined sausage groups during drying and ripening.

Table 3 Correlations between biogenic amines contents in three examined groups.

\begin{tabular}{llll}
\hline Biogenic amines & \multicolumn{2}{c}{ Correlation coefficient } \\
\cline { 2 - 4 } TRY-PHE & $\mathrm{A} 1$ & $\mathrm{~B} 1$ & $\mathrm{~B} 3$ \\
TRY-PUT & $0.41^{*}$ & $0.74^{* *}$ & $0.96^{* *}$ \\
TRY-CAD & $0.65^{* *}$ & $0.56^{* *}$ & $0.96^{* *}$ \\
TRY-TYR & $0.56^{* *}$ & $0.93^{* *}$ & $0.97^{* *}$ \\
TRY-Total & $0.46^{* *}$ & $0.59^{* *}$ & $0.98^{* *}$ \\
PHE-PUT & $0.71^{* *}$ & $0.77^{* *}$ & $0.71^{* *}$ \\
PHE-CAD & $0.90^{* *}$ & $0.96^{* *}$ & $0.98^{* *}$ \\
PHE-TYR & $0.13^{\mathrm{NS}}$ & $0.90^{* *}$ & $0.99^{* *}$ \\
PHE-Total & $0.90^{* *}$ & $0.95^{* *}$ & $0.96^{* *}$ \\
PUT-CAD & $0.03^{\mathrm{NS}}$ & $0.24^{\mathrm{NS}}$ & $0.57^{* *}$ \\
PUT-TYR & $0.58^{* *}$ & $0.00^{\mathrm{NS}}$ & $1.00^{* *}$ \\
PUT-Total & $0.95^{* *}$ & $0.97^{* *}$ & $0.97^{* *}$ \\
CAD-TYR & $0.10^{\mathrm{NS}}$ & $0.02^{\mathrm{NS}}$ & $0.50^{* *}$ \\
CAD-Total & $0.62^{* *}$ & $0.18^{\mathrm{NS}}$ & $0.97^{* *}$ \\
TYR-Total & $0.77^{* *}$ & $0.73^{* *}$ & $0.54^{* *}$ \\
\hline TRY:Tryptani & $0.12^{\mathrm{NS}}$ & $0.69^{* *}$ \\
\hline
\end{tabular}

TRY: Tryptamine, PHE: phenylethylamine, PUT: putrescine, CAD: cadaverine.

Correlation coefficient values marked with NS indicate no statistically significant correlation, values marked with $*$ indicate significant correlation $(P<0.05)$ and values marked with ** indicate very significant correlation $(P<0.01)$.

fact that biogenic amines contribute to the aroma of sausage [33], it is better to produce this traditional sausage from cold meat using slow processes of drying and ripening.

Accumulation of free amino acids as well as formation of specific sausage properties is consequence of proteolysis during ripening.
Availability of precursors (i.e., amino acids) and the presence of amino acid decarboxylases producing microorganisms and favourable conditions for their growth and activity, are necessary preconditions for biogenic amines formation [1, 2, 4]. Formation and changes in the type and content of biogenic amines can be different, even when the final product has been 
produced from the same raw material. The fact is that amines formation is influenced by numerous factors, and their complex interaction is also conformed in this study. Among these factors, the raw materials used in this experiment (hot deboned and cold meat) and the use of an appropriate drying model, certainly took an important role and had impact on the dynamics of proteolysis.

\section{Conclusions}

Histamine, the most important amine from food safety point of view, was not found in any of the analyzed samples. Total level of biogenic amines in all investigated sausages did not exceed $174 \mathrm{mg} / \mathrm{kg}$ at the end of drying and $238 \mathrm{mg} / \mathrm{kg}$ at the end of ripening period. Tryptamine and cadaverine may be used as indicators of total biogenic amines for sausages produced in traditional and industrial conditions from hot deboned and cold meat.

Amines formation is influenced by numerous factors and their complex interaction is conformed in this study. Among these factors, raw material and production conditions had an important role and influenced the dynamics of proteolysis.

\section{Acknowledgments}

This study was supported and financed by the Ministry of Science and Technological Development of the Republic of Serbia, Project No. TR 31032.

\section{References}

[1] Santos, M. H. S. 1996. "Biogenic Amines: Their Importance in Foods." International Journal of Food Microbiology 29 (2-3): 213-31.

[2] Suzzi, G., and Gardini, F. 2003. "Biogenic Amines in Dry Fermented Sausages: A Review.” International Journal of Food Microbiology 88 (1): 41-54.

[3] Vidal-Carou, M. C., Izquierdo-Pulido, M. L., Martin-Morro, M. C., and Mariné-Font, A. 1990. "Histamine and Tyramine in Meat Products: Relationship with Meat Spoilage." Food Chemistry 37 (4): 239-49.

[4] Shalaby, A. R. 1996. "Significance of Biogenic Amines to Food Safety and Human Health." Food Research International 29 (7): 675-90.
[5] Karovičova, J., and Kohajdova, Z. 2005. "Biogenic Amines in Food." Chemical Papers 59: 70-9.

[6] Hernndez-Jover, T., Izquierdo-Pulido, M., Veciana-Nogus, M. T., and Vidal-Carou, M. C. 1996. "Biogenic Amine Sources in Cooked Cured Shoulder Pork.” J. Agric. Food Chem. 44 (10): 3097-101.

[7] Hernández-Jover, T., Izquierdo-Pulido, M., Veciana-Nogus, M. T., and Vidal-Carou, M. C. 1996. "Ion Pair High-Performance Liquid Chromatographic Determination of Biogenic Amines in Meat and Meat Products.” J. Agric. Food Chem. 44 (9): 2710-5.

[8] Latorre-Moratalla, M. L., Veciana-Nogués, T., Bover-Cid, S., Garriga, M., Aymerich, T., Zanardi, E., Ianieri, A., Fraqueza, M. J., Patarata, L., Drosinos, E. H., Lauková, A., Talon, R., and Vidal-Carou, M. C. 2008. "Biogenic Amines in Traditional Fermented Sausages Produced in Selected European Countries." Food Chemistry 107 (2): 912-21.

[9] Kim, M. J., and Kim, K. S. 2014. "Tyramine Production among Lactic Acid Bacteria and Other Species Isolated from Kimchi." LWT-Food Science and Technology 56 (2): 406-13.

[10] Stratton, J. E., Hutkins, R. V., and Taylor, S. L. 1991. "Biogenic Amines in Cheese and Other Fermented Foods: A Review." Journal of Food Protection 54: 460-70.

[11] Eerola, H. S., Roig Sagues, A. X., and Hirvi, T. K. 1998. "Biogenic Amines in Finnish Dry Sausages." Journal of Food Safety 18 (2): 127-38.

[12] Bover-Cid, S., Izquierdo-Pulido, M., and Vidal-Carou, M. C. 2001. "Changes in Biogenic Amine and Polyamine Contents in Slightly Fermented Sausages Manufactured with and without Sugar.” Meat Science 57 (2): 215-21.

[13] Önal, A. 2007. "A Review: Current Analytical Methods for the Determination of Biogenic Amines in Foods." Food Chemistry 103 (4): 1475-86.

[14] Latorre-Moratalla, M. L., Bover-Cid, S., Talon, R., Aymerich, T., Garriga, M., Zanardi, E., Ianieri, A., Fraqueza, M. J., Elias, M., Drosinos, E. H., Lauková, A., and Vidal-Carou, M. C. 2010. "Distribution of Aminogenic Activity among Potential Autochtonous Starter Cultures for Dry Fermented Sausages.” Journal of Food Protection 73 (3): 524-8.

[15] Ikonić, P., Petrović, L., Tasić, T., Džinić, N., Jokanović, M., and Tomović, V. 2010. "Physicochemical, Biochemical and Sensory Properties for the Characterization of Petrovská klobása (Traditional Fermented Sausage)." Acta Periodica Technologica 41: 19-31.

[16] Tasić, T., Petrović, L., Ikonić, P., Mandić, A., Savatić, S., Jokanović, M., and Tomović, V. 2010. "Biogenic Amines in Traditional Dry Fermented Sausage Petrovská klobása Dried in Traditional Room and Industrial 
Ripening Chamber." In Proceedings of the XII International Meat Techmology Symposium "NODA 2010”, 148-54.

[17] Ikonić, P., Tasić, T., Petrović, L., Jokanović, M., Savatić, S., Tomović, V., Džinić, N., and Šojić, B. 2011. "Effect of Drying and Ripening Methods on Proteolysis and Biogenic Amines Formation in Traditional Dry-Fermented Sausage Petrovská klobása." Food \& Feed Research 38 (1): 1-8.

[18] Bover-Cid, S., Izquierdo-Pulido, M., and Vidal-Carou, M. C. 2001. "Effect of the Intercation between a Low Tyramine-Producing Lactobacillus and Proteolitic Staphylococci on Biogenic Amine Production during Ripening and Storage of Dry Sausages." International Journal of Food Microbiology 65 (1-2): 113-23.

[19] Parente, E., Martuscelli, M., Gardini, F., Grieco, S., Crudele, M. A., and Suzzi, G. 2001. "Evolution of Microbial Populations and Biogenic Amine Production in Dry Sausages Produced in Southern Italy." Journal of Applied Microbiology 90 (6): 882-91.

[20] Lebert, I., Leroy, S., Giammarinaro, P., Lebert, A., Chacornac, J. P., Bover-Cid, S., Vidal-Carou, M. C., and Talon, R. 2007. "Diversity of Microorganisms in the Environment and Dry Fermented Sausages of Small Traditional French Processing Units." Meat Science 76 (1): 112-22.

[21] Eerola, S., Hinkkanen, R., Lindfors, E., and Hirvi, T. 1993. "Liquid Chromatographic Determination of Biogenic Amines in Dry Sausages." Journal of AOAC International 76 (3): 575-7.

[22] Tasić, T., Ikonić, P., Mandić, A., Jokanović, M., Tomović, V., Savatić, S., and Petrović, L. 2012. "Biogenic Amines Content in Traditional Dry Fermented Sausage Petrovská klobása as Possible Indicator of Good Manufacturing Practice." Food Control 23 (1): 107-12.

[23] Bover-Cid, S., Miguelez-Arrizado, J., Latorre-Moratalla, L. L., and Vidal-Carou, M. C. 2006. "Freezing of Meat Raw Materials Affects Tyramine and Diamine Accumulation in Spontaneously Fermented Sausages." Meat Science 72 (1): 62-8.

[24] Hernndez-Jover, T., Izquierdo-Pulido, M., Veciana-Nogus, M. T., Marin-Font, A., and Vidal-Carou,
M. C. 1997. "Biogenic Amine and Polyamine Contents in Meat and Meat Products." J. Agric. Food Chem. 45 (6): 2098-102.

[25] Komprda, T., Smělá, D., Pechová, P., Kalhotka, L., Štencl, J., and Klejdus, B. 2004. "Effect of Starter Culture, Spice Mix and Storage Time and Temperature on Biogenic Amine Content of Dry Fermented Sausages." Meat Science 67 (4): 607-16.

[26] Bardócz, S. 1995. "Polyamines in Food and Their Consequences for Food Quality and Human Health." Trends in Food Science \& Technology 6 (10): 341-6.

[27] Butturini, A., Aloisi, P., Tagliazucchi, R., and Cantoni, C. 1995. "Biogenic Amines Production by Enterobacteria and Lactic Acid Bacteria.” Industrie Alimentari 24: 105-7. (in Italian)

[28] Giraffa, G., Pepe, G., Locci, F., Neviani, E., and Carminati, D. 1995. "Haemolytic Activity, Production of Thermonuclease and Biogenic Amines by Dairy Enterococci." Italian Journal of Food Science 7 (4): 341-9.

[29] Verplaetse, A. 1994. "Influence of Raw Meat Properties and Processing Technologyon Aroma Quality of Raw Fermented Meat Products." In Proceedings of the 40th International Congress of Meat Science and Technology, 45-65.

[30] Toldra, F. 1998. "Proteolysis and Lipolysis in Flavour Development of Dry-Cured Meat Products." Meat Science 49 (1): 101-10.

[31] Sanz, Y. S., Fadda, S., Vignolo, G., Aristoy, M. C., Oliver, G., and Toldra, F. 1999. "Hydrolysis of Muscle Myofibrillar Proteins by Lactobacillus curvatus and Lactobacillus sake." International Journal of Food Microbiology 53 (2-3): 115-25.

[32] Mauriello, G., Casaburi, A., and Villani, F. 2002. "Proteolytic Activity of Staphylococcus xylosus Strains on Pork Myofibrillar and Sarcoplasmic Proteins and Use of Selected Strains in the Production of Naples Type Salami." Journal of Applied Microbiology 92 (3): 482-90.

[33] Halász, A., Baráth, A., Simon-Sarkadi, L., and Holzapfel, W. 1994. "Biogenic Amines and Their Production by Microorganisms in Food." Trends in Food Science and Technology 5 (2): 42-9. 